\title{
Variations in the sulfide regime and the distribution of macrofauna in an intertidal flat in the North Sea
}

\author{
F. Thiermann, A.-S. Niemeyer \& O. Giere \\ Zoologisches Institut und Zoologisches Museum, Universität Hamburg; \\ Martin-Luther-King-Platz 3, 20146 Hamburg, Germany
}

Manuscript received on 9th November 1993; accepted for publication on 8th July 1994

\begin{abstract}
Sulfide concentrations were measured in the inner and outer Königshafen (Sylt, Wadden Sea) from November 1990 to December 1991 to assess the fluctuations of sulfide levels in natural tidal habitats. Three different areas were compared: (1) muddy sediment, (2) fine-medium sand, and (3) a mussel bed. Other abiotic factors such as $\mathrm{Eh}, \mathrm{pH}$, temperature, grain size and organic content were measured. After assessment of the macrofaunal distribution, an attempt was made to relate the distribution to the sulfide concentrations in the benthic habitat. Sulfide concentrations varied between sites throughout the year with considerable differences ranging from below $5 \mu \mathrm{M}$ (limit of detection) to about $1 \mathrm{mM}$ (Oct. 1991). The faunal composition (Table 2) at the different sites hardly varied; it was always dominated by annelids: The cirratulid Tharyx marioni was the most abundant species in the upper layers of all sites, where it occurred at low sulfide concentrations $(<50 \mu \mathrm{M})$. Heteromastus filiformis was commonly found in the deeper sediment layers of the muddy site where it was regularly exposed to sulfide levels around $75 \mu \mathrm{M}$ and peak concentrations in autumn up to $1 \mathrm{mM}$. Capitella capitata, Tubificoides pseudogaster and Tubificoides benedii were very common in the upper sediment layers where sulfide levels were about $150 \mu \mathrm{M}$ in autumn. These species also occurred, however, in the deeper layers with higher sulfide concentrations. These results document not only the wide annual range of sulfide concentrations at different depths in a tidal flat, they also emphasize that under natural conditions tidal flat annelids are exposed to considerable concentrations of hydrogen sulfide.
\end{abstract}

\section{INTRODUCTION}

Next to dissolved oxygen, sulfide is a key factor for the marine benthos and its distribution (e.g. Vismann, 1991; Grieshaber et al., 1994). Nevertheless, in studies on the endobenthos, sulfide concentrations are rarely measured in the natural porewater.

In this study, field data on sulfide concentrations and macrofaunal distribution (comprising mainly annelids) were collected over 14 months (Nov. 1990-Dec. 1991) to contribute a baseline study to the knowledge of annual cycling as well as fluctuations in the tidal sulfide biome. The three study sites in the Königshafen (Sylt, Wadden Sea) differed in sediment composition. Besides the sulfide measurements, other factors were recorded such as $\mathrm{pH}, \mathrm{Eh}$, temperature, salinity, grain size and organic content. 


\section{MATERIAL AND METHODS}

\section{Study area}

Sampling sites (Fig. 1) were located in the "Königshafen", a sheltered intertidal sand flat in the vicinity of the northern part of the island of Sylt (North Sea). The mean tidal range is about $1.7 \mathrm{~m}$; seawater salinity varies between $26 \%$ and $32 \% \mathrm{~S}$, with a mean salinity of $30 \% \mathrm{~S}$. A more detailed description of the area is given by Wohlenberg (1937) and Reise (1985).

Three different sites were sampled.

Si te 1: Located in the inner Königshafen (Westfeuerwatt) close to a tideway. Some sparse mussel beds occurred in this rather muddy area (the Königshafen consists generally of fine sand).

Site 2: Close to the dyke (approximately $10 \mathrm{~m}$ away) in the outer Königshafen (Oddewatt) where the sediment was coarser than in Site 1. A layer of broken shells appeared in the sediment at a depth of approximately $15 \mathrm{~cm}$, and some plant material was mixed with the sediment. Next to this site, large mats of green algae have occurred in recent years during warm and calm periods, although not during the sampling period.

S it e 3: At the very edge of a larger mussel bank with Fucus plants, 20 m seawards from Site 2. The sediment consisted of poorly sorted coarser sands, the upper layer was occasionally covered with recently sedimentated mud and Fucus debris.

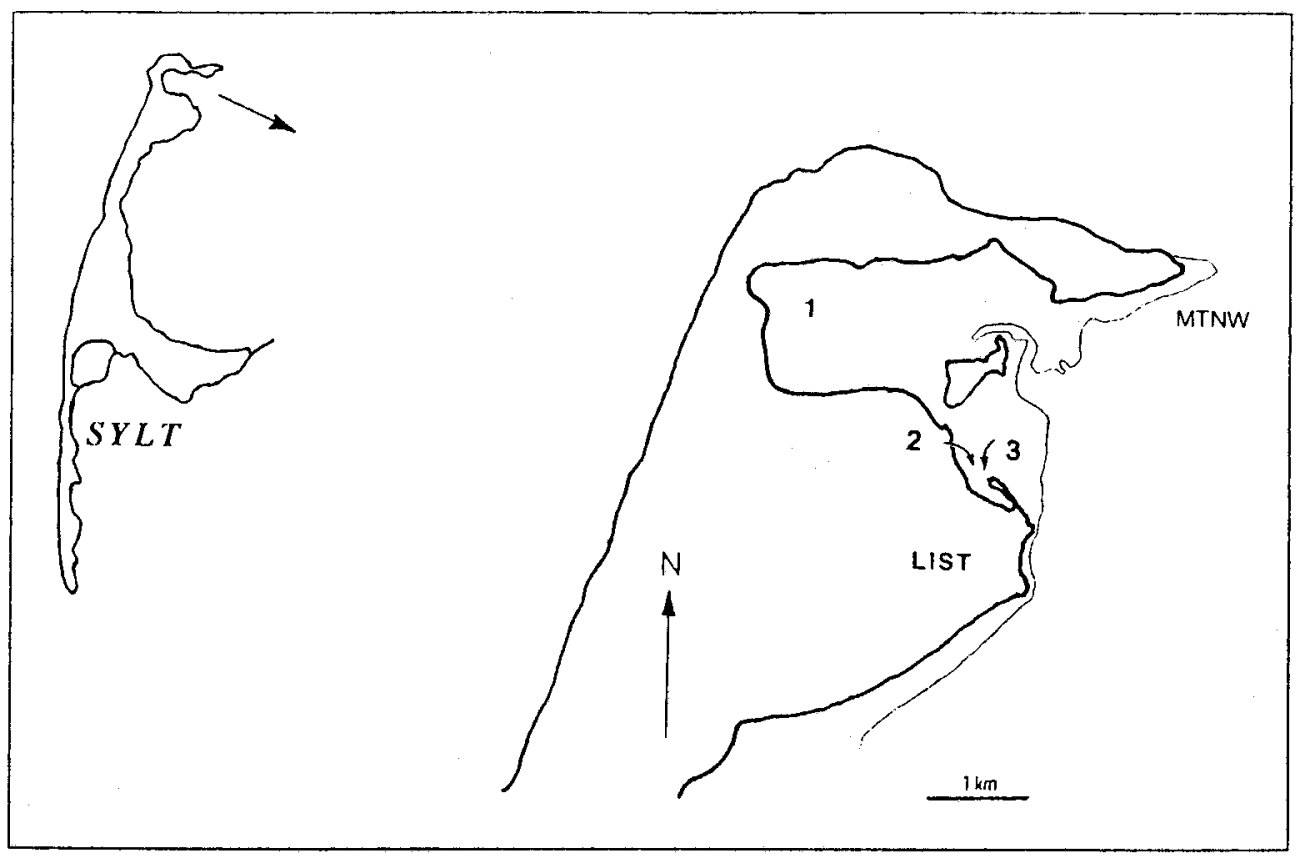

Fig. 1. Map of sampling area: "Königshafen" on the island of Sylt (North Sea, Northern Germany) with the three sampling sites: 1: Westfeuerwatt (muddy-fine sand); 2: Oddewatt (fine-medium sand); 3: mussel bed in the Oddewatt (fine-medium sand) 


\section{Sampling procedure}

Macrofauna samples were taken during low-tide periods, almost monthly from November 1990 to December 1991. Environmental conditions and the sampling procedure allowed three replicates to be taken per site during one low-tide period. Sulfide, temperature, redox potential (Eh), $\mathrm{pH}$, grain size distribution and the content of organic carbon were determined at each sampling site and occasion.

Sulfide samples: Parallel to the fauna sampling, the sulfide concentrations were measured. Porewater samples for sulfide measurements were obtained at three different depths: $4 \mathrm{~cm}, 9 \mathrm{~cm}$ and $14 \mathrm{~cm}$. Specially constructed porewater suction corers (modified after Howes et al., 1985) and medical syringes (1 ml) were used to extract 0.2-1 ml clear porewater for the analyses. Three replicates from each depth were taken and evaluated. Each sample was fixed in prepared glass vials with $2 \mathrm{ml}$ of $0.12 \mathrm{M}$ zinc acetate and $0.5 \mathrm{ml} 1.5 \mathrm{M}$ sodiumhydroxide. Sulfide concentration was measured colorimetrically (after Gilboa-Garber, 1971, modified as described by Howarth et al., 1983).

$\mathrm{Sediment} \mathrm{s}$ a mples: Sediment samples for analyses of grain size and organic carbon content were collected with perspex corers (internal diameter $5 \mathrm{~cm}$ ) to a depth of $15 \mathrm{~cm}$. The samples were subdivided into $5-\mathrm{cm}$ fractions and immediately frozen after return to the laboratory. Grain size distribution and the content of organic carbon were analysed according to commonly used procedures (Buchanan, 1984; Giere et al., 1988).

In the field, $\mathrm{pH}$ and the redoxpotential (Eh) were measured with insertion electrodes. Values were obtained from $4 \mathrm{~cm}, 9 \mathrm{~cm}$, and $14 \mathrm{~cm}$. Sediment and air temperature were measured with a thermistor. Salinity in the pore water and in the surface water was determined refractometrically. The porewater was obtained with suction corers as described for the sulfide samples.

Macrofauna: Macrofauna was collected with a perspex sediment corer (inner diameter $11 \mathrm{~cm}$ ). The cores were subdivided into three fractions: $0-5 \mathrm{~cm}, 5-10 \mathrm{~cm}$ and $10-15 \mathrm{~cm}$. These subsamples were hand-sieved in the laboratory through a 500-um-mesh sieve. Immediately after sieving, the sample content was preserved in buffered formalin (di-sodiumhydrogenphosphate/sodium-di-hydrogenphosphate, final concentration of formalin approximately $4 \%$ ).

The fauna was evaluated qualitatively and quantitatively under a dissecting microscope. Sorted animals were stored in $70 \%$ ethanol.

\section{RESULTS}

Grain-size distribution (Table 1): The median diameter (MD) indicated that the sediment of Site 1 consists of fine to very fine sand. The sediment of Sites 2 and 3 were coarser (fine to medium sand). The "Inclusive Graphic Quartile Deviation" (QDI) showed that most of the sediment samples were moderately sorted. Only Site 3 consisted mainly of poorly sorted sand fractions.

$\mathrm{Sulf}$ ide concentration: The results indicate that sulfide was present in the sediment throughout the year (Fig. 2) with an increasing trend in the warmer season, mainly from July/August to October 1991 at Sites 1 and 3. Site 2 was permanently exposed to moderate sulfide concentrations (between $<5$ and $35 \mu \mathrm{M}$ ) and showed no peak values in summer. Highest values $(1147 \mu \mathrm{M})$ were measured in October 1991 at Site 1 at $14 \mathrm{~cm}$ sediment depth. 
Table 1. Grain size composition and sorting coefficient of the three sampling sites. Md $=$ mean diameter; $\mathrm{QDI}=$ sorting coefficient

\begin{tabular}{|cll}
\hline Site 1 & & \\
\hline Sediment-fraction & \multicolumn{1}{c}{ Md $(\mu \mathrm{m})$} & QDI \\
\hline $0-5 \mathrm{~cm}$ & 143 (fine sand) & 0.94 (moderately sorted) \\
$5-10 \mathrm{~cm}$ & 123 (very fine - fine sand) & 0.96 (moderately sorted) \\
$10-15 \mathrm{~cm}$ & 129 (very fine - fine sand) & 0.86 (moderately sorted)
\end{tabular}

Site 2

\begin{tabular}{cll}
\hline Sediment-fraction & \multicolumn{1}{c}{ Md $(\mu \mathrm{m})$} & QDI \\
\hline $0-5 \mathrm{~cm}$ & 239 (fine sand) & 0.86 (moderately sorted) \\
$5-10 \mathrm{~cm}$ & 257 (fine - medium sand) & 0.89 (moderately sorted) \\
$10-15 \mathrm{~cm}$ & 329 (fine - medium sand) & 0.89 (moderately sorted) \\
\hline
\end{tabular}

Site 3

Sediment-fraction

$\mathrm{Md}(\mu \mathrm{m})$

QDI

$0-5 \mathrm{~cm}$

$5-10 \mathrm{~cm}$

$10-15 \mathrm{~cm}$
323 (fine - medium sand)

295 (fine - medium sand)

447 (medium sand)
1.01 (poorly sorted)

1.13 (poorly sorted)

0.97 (moderately sorted)

There was no general trend relating increasing sulfide concentration to increasing sediment depth. During the whole sampling period, only Site 1 showed higher concentrations at $14 \mathrm{~cm}$ depth than in shallower depths.

Eh, temperature and salinity: Redox depth profiles revealed no general pattern. The Eh values varied from +480 to $-100 \mathrm{mV}$, but in general, these values were clearly within a positive range and there were no general patterns regarding decreasing values with the depth.

The lowest sediment temperatures $\left(-0.8^{\circ} \mathrm{C}\right)$ were measured in December 1991 at Site 2 at a depth of $9 \mathrm{~cm}$. They increased during the summer to max. $22.6^{\circ} \mathrm{C}$ in July, also at Site 2 in $4 \mathrm{~cm}$ depth.

At Site 1 and Site 2 no extreme changes in porewater salinity were recorded $(34-36 \%$ o). However, Site 3 showed a higher variability in porewater salinity, i.e. $30 \%$ (July/Oct.) and $37 \%$ in September.

$\mathrm{Mac}$ of a u a : The complete species list found at the sampling stations is given in Table 2 .

The species assemblage at the three sites (Table 3) consisted of fairly similar elements; the mussel bed (Site 3), however, differed in that it had a reduced number of species and abundance ranging from 78 ind. $/ 100 \mathrm{~cm}^{2}$ in November 1991 to max. 472 ind./ $100 \mathrm{~cm}^{2}$ in March 1991. Values were commonly between 200 and nearly 400 individuals 
Table 2. List of macrofauna species found at the three sampling sites in Königshafen, North Sea

\begin{tabular}{|c|c|}
\hline $\begin{array}{l}\text { NEMERTINI } \\
\text { Lineus viridis } \\
\text { Amphiporus lactiflorens } \\
\text { BIVALVIA } \\
\text { Mytilidae } \\
\text { Mytilus edulis } \\
\text { Cardiidae } \\
\text { Cerastoderma edule } \\
\text { Tellinidae } \\
\text { Macoma baithica } \\
\text { Myidae } \\
\text { Mya arenaria } \\
\text { OLIGOCHAETA } \\
\text { Tubificidae } \\
\text { Tubificoides benedii } \\
\text { Tubificoides pseudogaster } \\
\text { POLYCHAETA } \\
\text { Arenicolidae } \\
\text { Arenicola marina } \\
\text { Ampharetidae } \\
\text { Ampharete finmarchica } \\
\text { Capitellidae } \\
\text { Capitella capitata } \\
\text { Heteromastus filiformis } \\
\text { Cirratulidae } \\
\text { Tharyx marioni }\end{array}$ & $\begin{array}{l}\text { Hesionidae } \\
\text { Microphthalmus spp. } \\
\text { Nephtydidae } \\
\text { Nephtys hombergi } \\
\text { Nereidae } \\
\text { Hediste diversicolor } \\
\text { Orbiniidae } \\
\text { Scoloplos armiger } \\
\text { Paranoidae } \\
\text { Aricidea minuta } \\
\text { Phyllodocidae } \\
\text { Anaitides maculata } \\
\text { Eteone longa } \\
\text { Spionidae } \\
\text { Malacoceros tetracercus } \\
\text { Pygospio elegans } \\
\text { Polydora ligni } \\
\text { Polydora quadrilobata } \\
\text { Spio filicornis } \\
\text { Streblospio benedicti } \\
\text { Syllidae } \\
\text { Exogone naidina } \\
\text { Terebellidae } \\
\text { Lanice conchilega } \\
\text { CRUSTACEA } \\
\text { Amphipoda } \\
\text { Corophium volutator }\end{array}$ \\
\hline
\end{tabular}

per $100 \mathrm{~cm}^{2}$. The two other sites resembled one another more closely in terms of number of species and abundance.

The fauna at the two first sites was quite similar. At S ite 1 (Figs $3 a-c$ ), the overall abundance increased from 188 (May 1991) to 717 (Nov. 1990) individuals per $100 \mathrm{~cm}^{2}$ over the total depth range of $15 \mathrm{~cm}$, and the average range was 400 to $600 \mathrm{ind} . / 100 \mathrm{~cm}^{2}$.

In the cooler season, the small cirratulid polychaete Tharyx marioni was the most abundant species in the upper sediment layers, reaching a peak abundance in November (up to 550 ind. $/ 100 \mathrm{~cm}^{2}$ in $0-5 \mathrm{~cm}$ depth and 247 ind. still in $5-10 \mathrm{~cm}$ depth). Other annelids dominating in the winter period were the oligochaetes Tubificoides benedii and T. pseudogaster. They reached maxima in January and March (T. benedii: 122 ind./ $100 \mathrm{~cm}^{2}$ and T. pseudogaster: 133 ind. $/ 100 \mathrm{~cm}^{2}$, Jan., 1991, 0-5 cm depth). During summer and autumn, their abundance decreased. As for their depth distribution, there are some indications that under low sulfidic conditions $T$. pseudogaster might inhabit somewhat deeper layers than $T$. benedii. During the warmer season, the nereid Hediste diversicolor dominated, attaining maxima from June to July $1991\left(1191 \mathrm{ind} . / 100 \mathrm{~cm}^{2}\right.$, 0-5 cm depth). Also the capitellid Heteromastus filiformis was a characteristic species of Site 1 ; it occupied regularly the deeper sediment layers, at 7 to 24 ind. $/ 100 \mathrm{~cm}^{2}$ (June to July 1991), but was scarce or absent from other sites. Anaitides maculata and Eteone longa were rarer species in the samples from Site $1\left(1\right.$ to 7 ind. $\left./ 100 \mathrm{~cm}^{2}\right)$. 

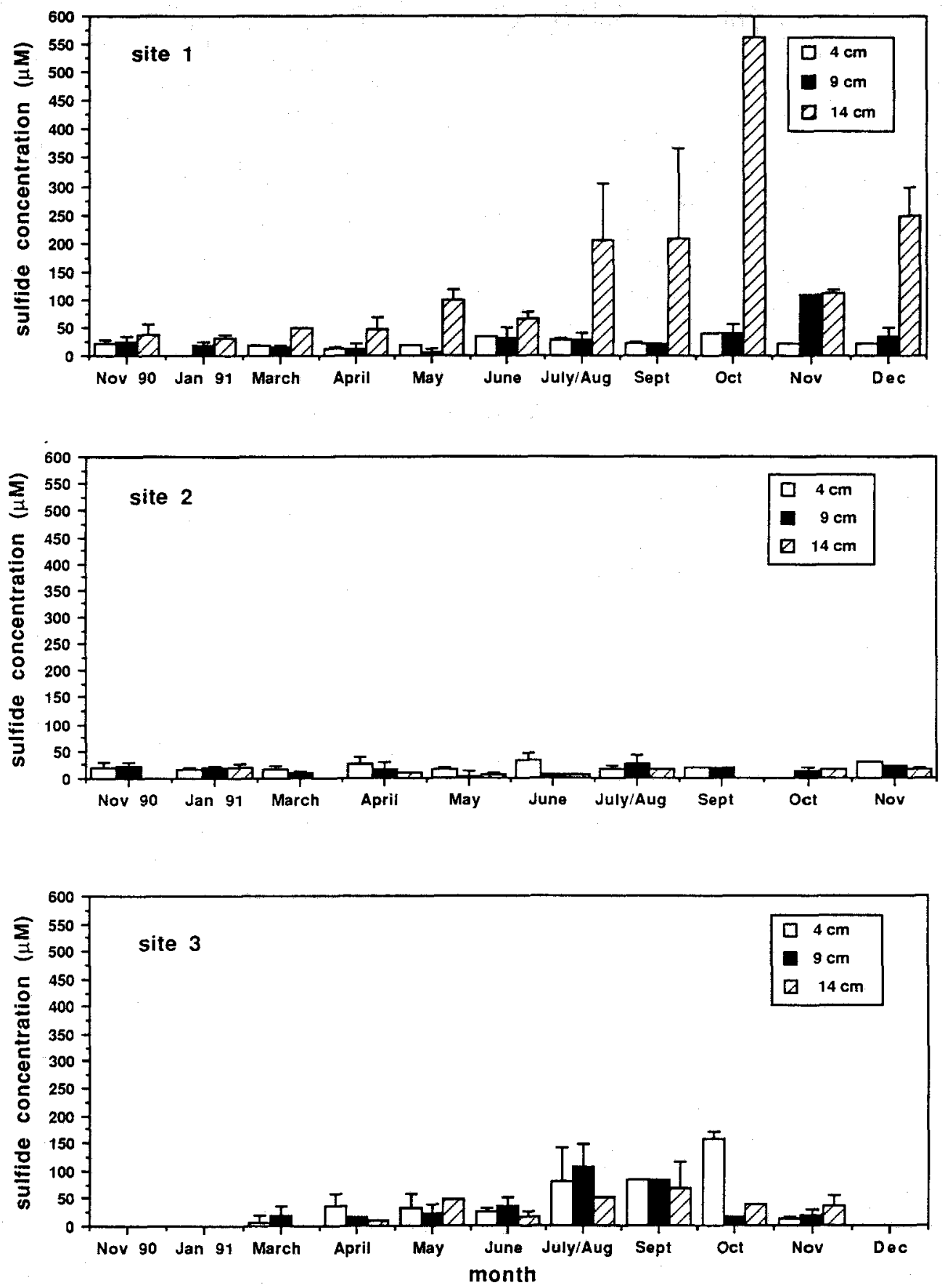

Fig. 2. Mean sulfide concentrations in 4-, 9- and 14-cm sediment depth during the sampling period. Site 1 (Westfeuerwatt), Site 2 (Oddewatt), Site 3 (mussel bed) 
Table 3. Semi-quantitative distribution of annelid species at the sampled localities

\begin{tabular}{|c|c|c|c|}
\hline Species & $\begin{array}{l}\text { Muddy sediment } \\
\text { (Site 1) }\end{array}$ & $\begin{array}{l}\text { Coarse sand } \\
\text { (Site 2) }\end{array}$ & $\begin{array}{l}\text { Mussel bed } \\
\text { (Site 3) }\end{array}$ \\
\hline Tharyx marioni & $\mathrm{x}-\mathrm{a} a$ & $x-a a$ & $\mathrm{x}-\mathrm{pa}$ \\
\hline Heteromastus filiformis & $x-a$ & $\mathrm{sp}$ & - \\
\hline Capitella capitata & $\mathbf{x}$ & $x-p a$ & $\mathrm{x}-\mathrm{pa}$ \\
\hline Scoloplos armiger & $\mathrm{sp}$ & $x-p a$ & $x \cdot p a$ \\
\hline Anaitides maculata & $\mathrm{x}$ & $\mathbf{x}$ & $\mathrm{x}$ \\
\hline Eteone longa & $\mathbf{x}$ & $\mathrm{x}$ & - \\
\hline Arenicola marina & $\mathrm{sp}$ & $\mathrm{sp}$ & - \\
\hline Aricidea minuta & $\mathrm{sp}$ & $\mathrm{sp}$ & - \\
\hline Microphthalmus spp. & $\mathrm{x}$ & $\mathrm{sp}$ & $\mathrm{x}-\mathrm{pa}$ \\
\hline Hediste diversicolor & $\mathrm{x}$-pa & $x-p a$ & $x-p a$ \\
\hline Exogone naidina & $\mathrm{x}$ & $\mathrm{x}$ & - \\
\hline Ampharete finmarchica & sp & $\mathrm{sp}$ & $\mathrm{sp}$ \\
\hline Pygospio elegans & $\mathrm{x}-\mathrm{pa}$ & $\mathrm{x}$-pa & $x-p a$ \\
\hline Spio filicornis & $\mathrm{sp}$ & $\mathrm{sp}$ & - \\
\hline Streblospio benedicti & $\mathrm{x}-\mathrm{pa}$ & $x-p a$ & $\mathrm{sp}$ \\
\hline Malacoceros tetracercus & $\mathrm{sp}$ & $\mathrm{x}-\mathrm{pa}$ & $x-p a$ \\
\hline Polydora spp. & $\mathrm{r}$ & $\mathrm{r}$ & $\mathrm{r}$ \\
\hline Tubificoides benedii & $\mathrm{x}-\mathrm{a}$ & $x-a$ & $x-a$ \\
\hline Tubificoides pseudogaster & $\mathrm{x}-\mathrm{a}$ & $\mathrm{x}-\mathrm{a}$ & $\mathrm{x}-\mathrm{a}$ \\
\hline
\end{tabular}

At Site 2 (Figs 4a-b), the overall peak of abundance was attained in March 1991 with 1020 ind. $/ 100 \mathrm{~cm}^{2}$ (from the surface to $15 \mathrm{~cm}$ depth). The lowest number of individuals occurred in April 1991 (95 individuals); however, variation between replicates was considerable, indicating the extreme patchiness of the benthos in the area. Again, polychaetes and oligochaetes were the dominant taxa.

The dominant species at Site 2 were Th. marioni and the two oligochaete species, Tubificoides benedii and $T$. pseudogaster, with highest abundances in January and March (e.g. Th. marioni 351 ind. $/ 100 \mathrm{~cm}^{2}, 0-5 \mathrm{~cm}$, in January; $T$. benedii with 551 ind./ $\mathrm{cm}^{2}$, and T. pseudogaster with 95 ind. $/ 100 \mathrm{~cm}^{2}, 0-5 \mathrm{~cm}$, in March). T. benedii reached considerable population sizes also in the summer months (June, Station 2.3: 322 ind. and July, Station 2.2: 308 ind. $/ 100 \mathrm{~cm}^{2}$, both in $0-5 \mathrm{~cm}$ ). In the upper layers, $T$. benedii always had higher numbers of individuals than $T$. pseudogaster which, as in Site 1, inhabited the deeper areas in higher abundances. In June, the populations of Capitella capitata, Scoloplos armiger and Pygospio elegans increased. C. capitella maintained a rich stock until December, but with a rather patchy distribution.

Site 3 (Figs $5 a-c$ ) was investigated from March to December 91. At this site, the oligochaetes Tubificoides benedii and $T$. pseudogaster were the most abundant species, with a clear prevalence for the cooler season, although the total number of benthic macrofauna declined in the autumn and winter. During this time, the oligochaetes populated the deeper sediment layers, whereas during the summer these layers were scarcely inhabited. 


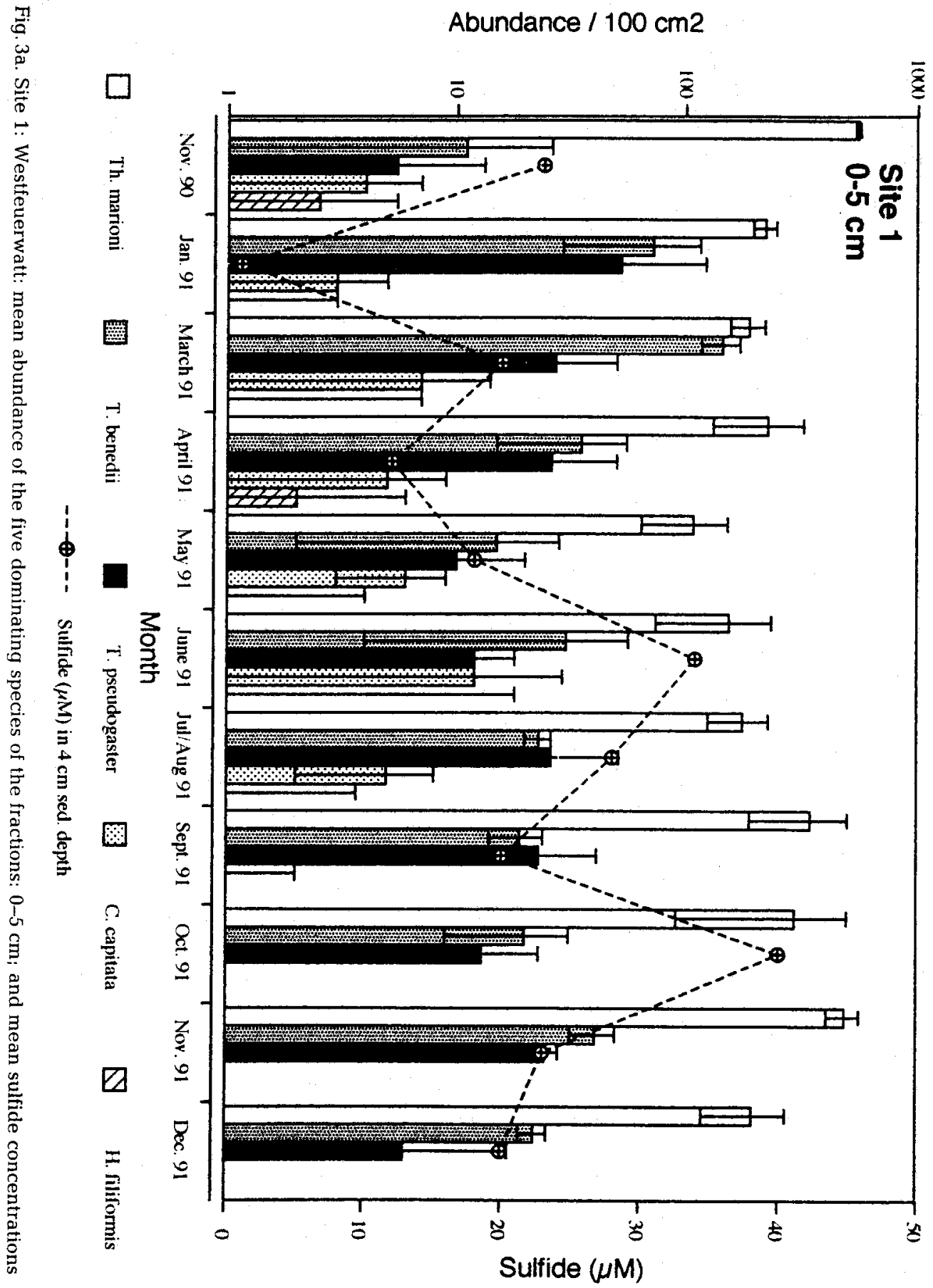




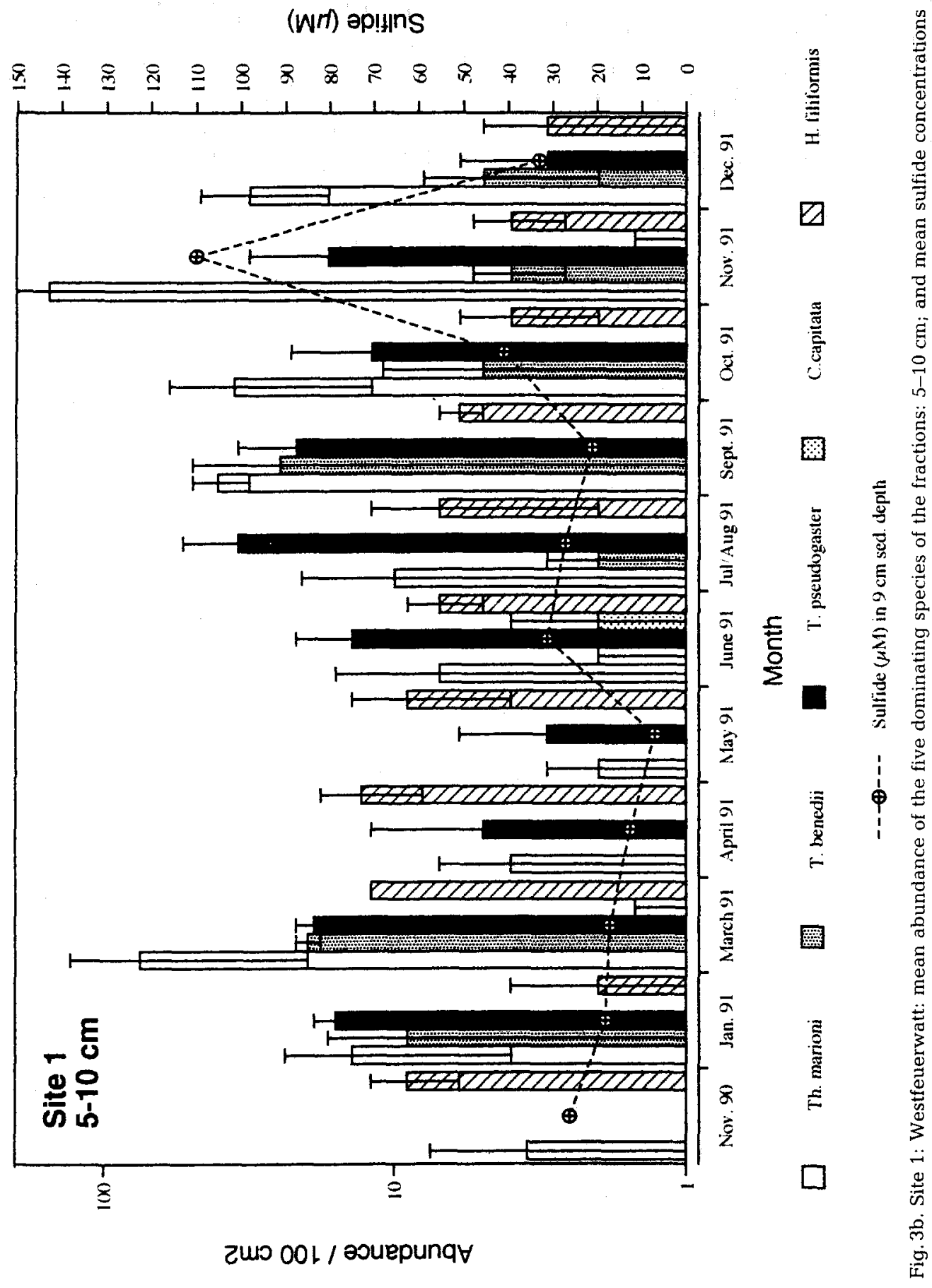




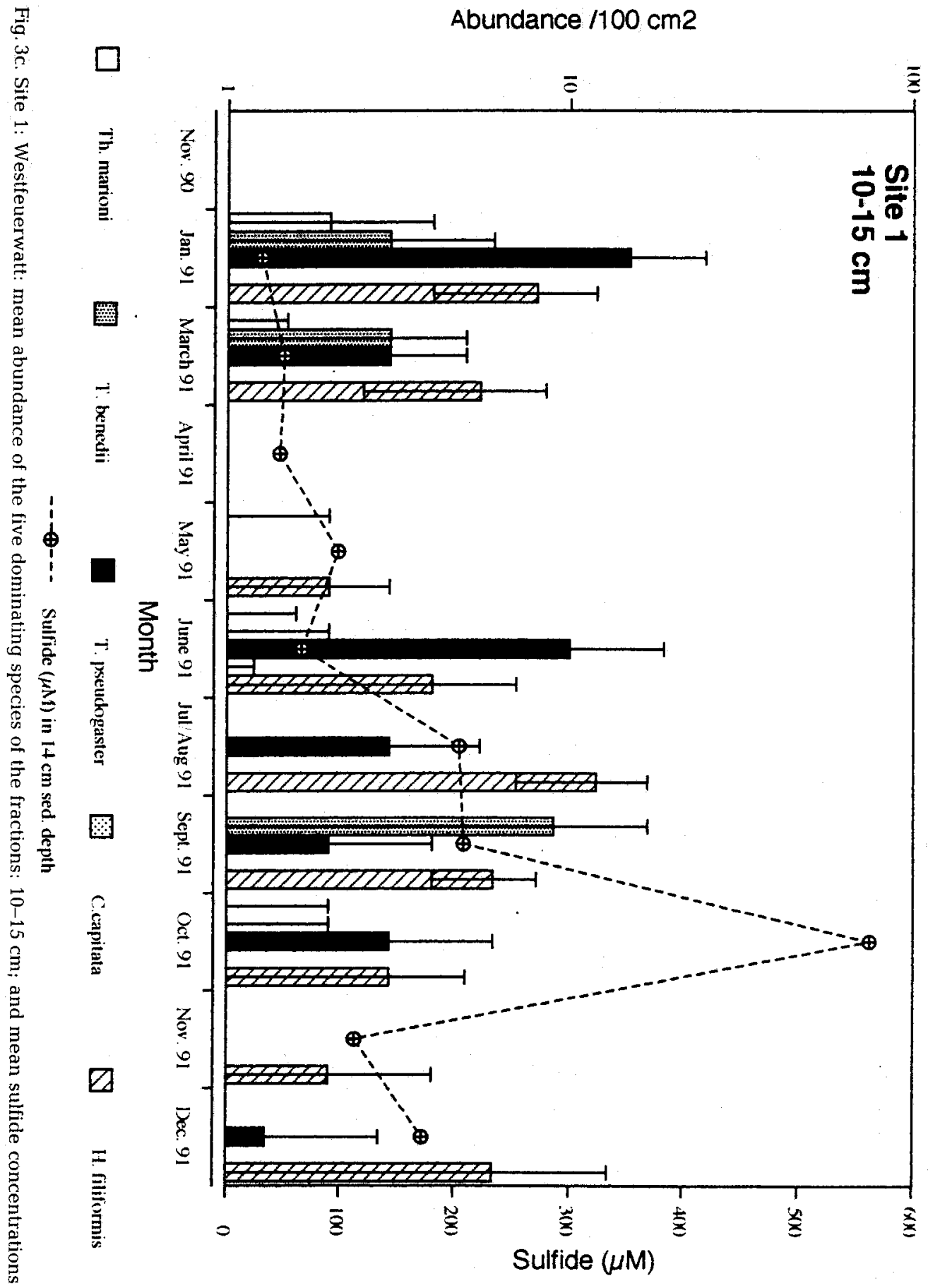




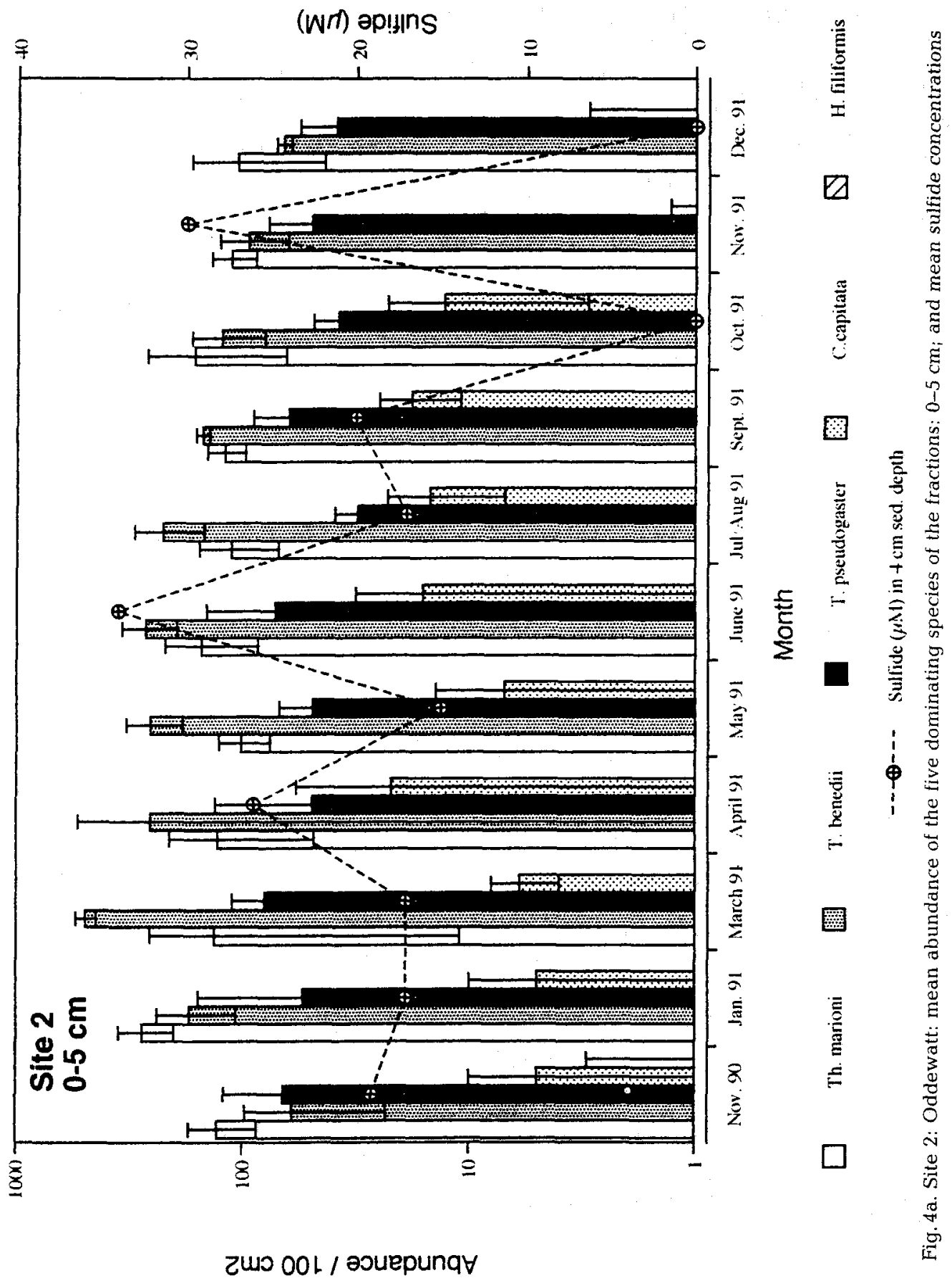




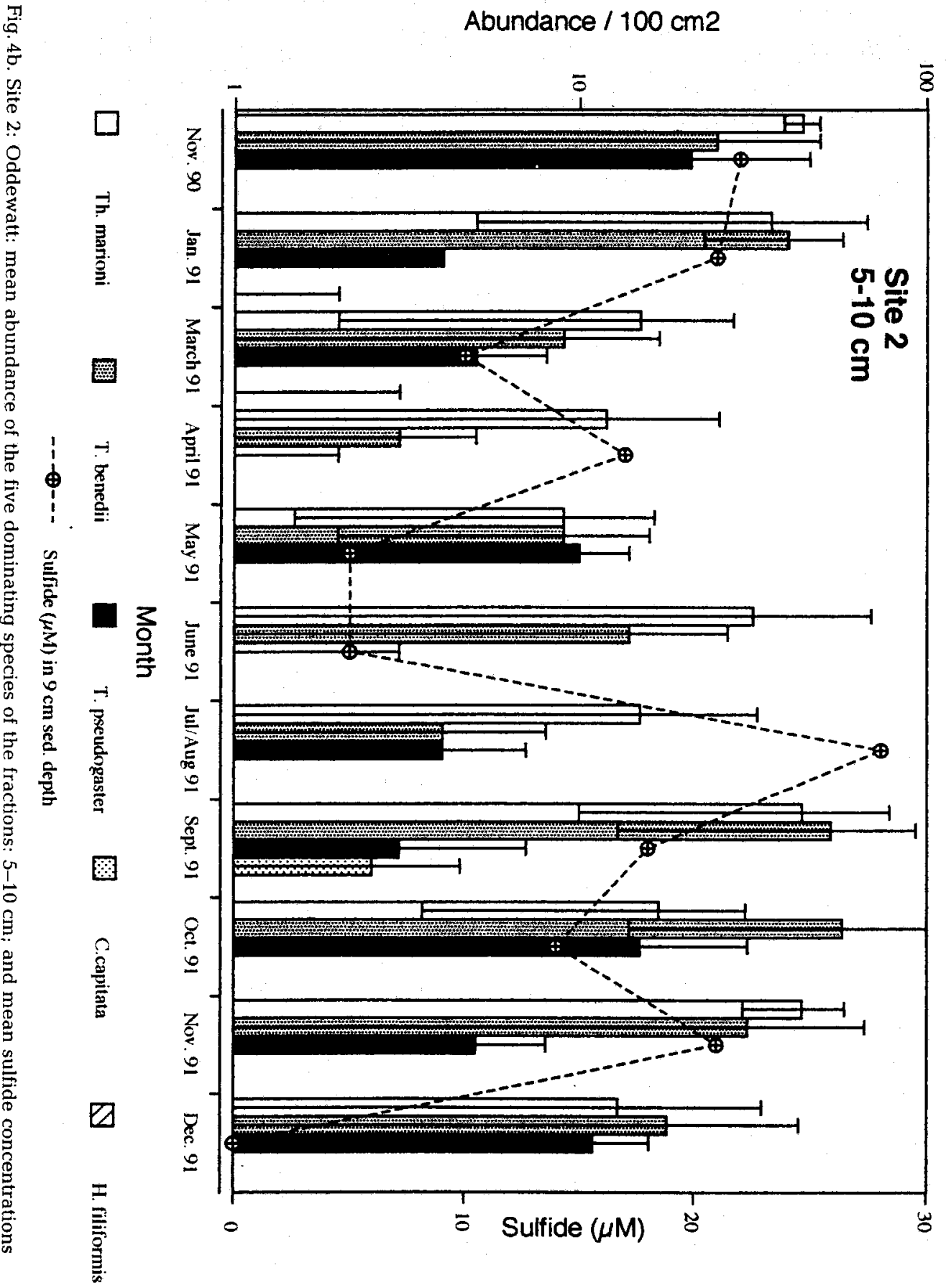




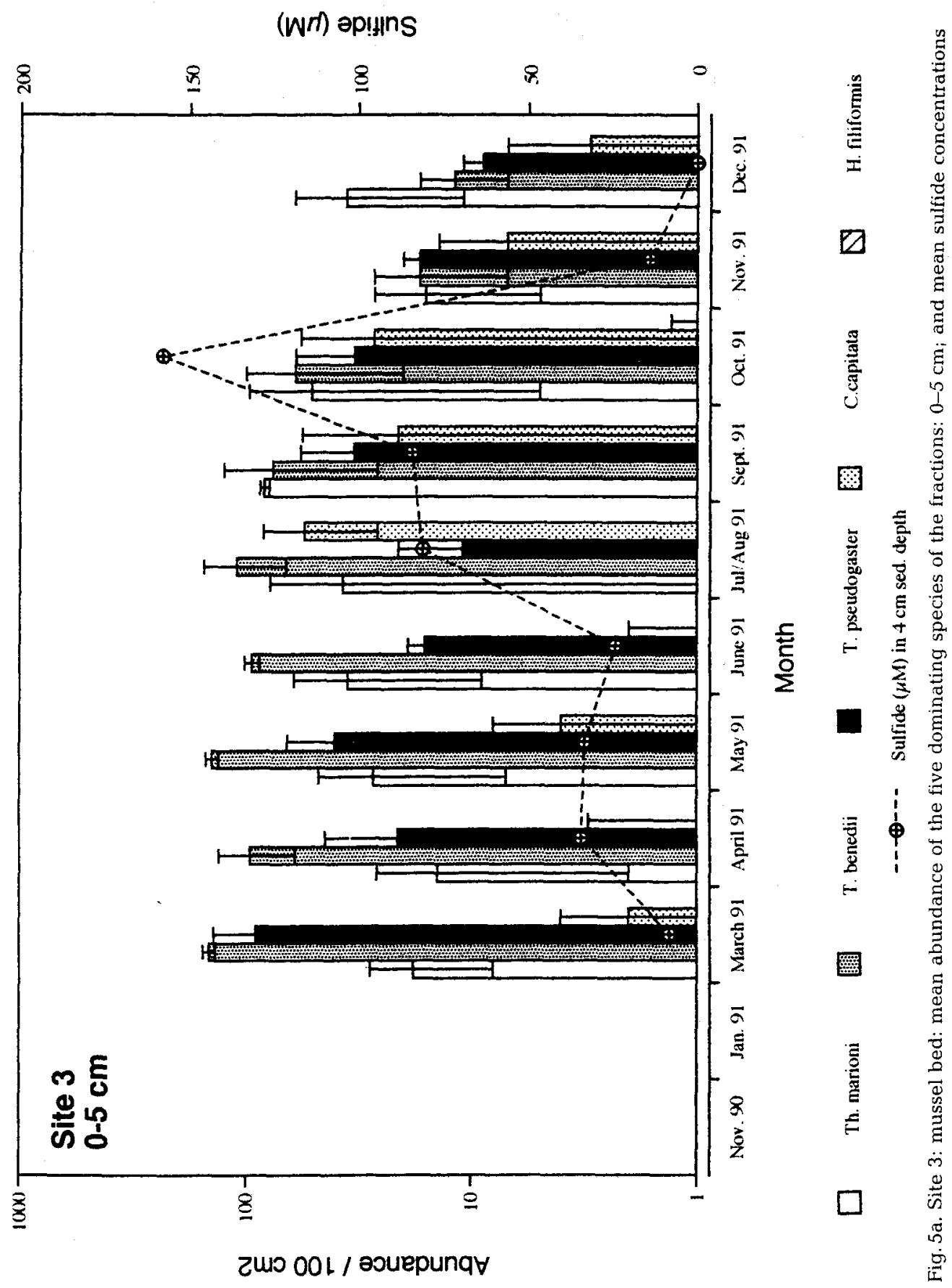




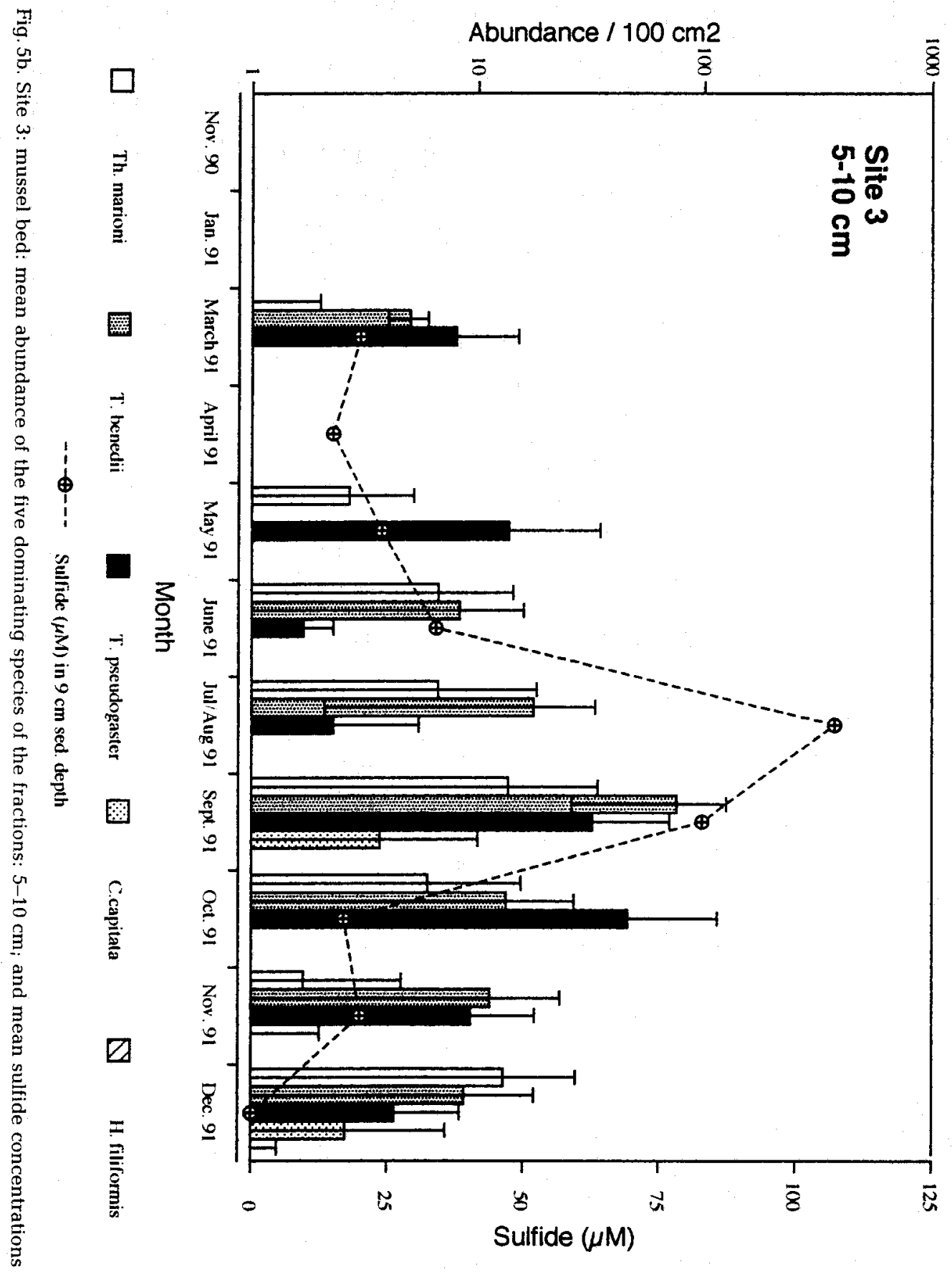




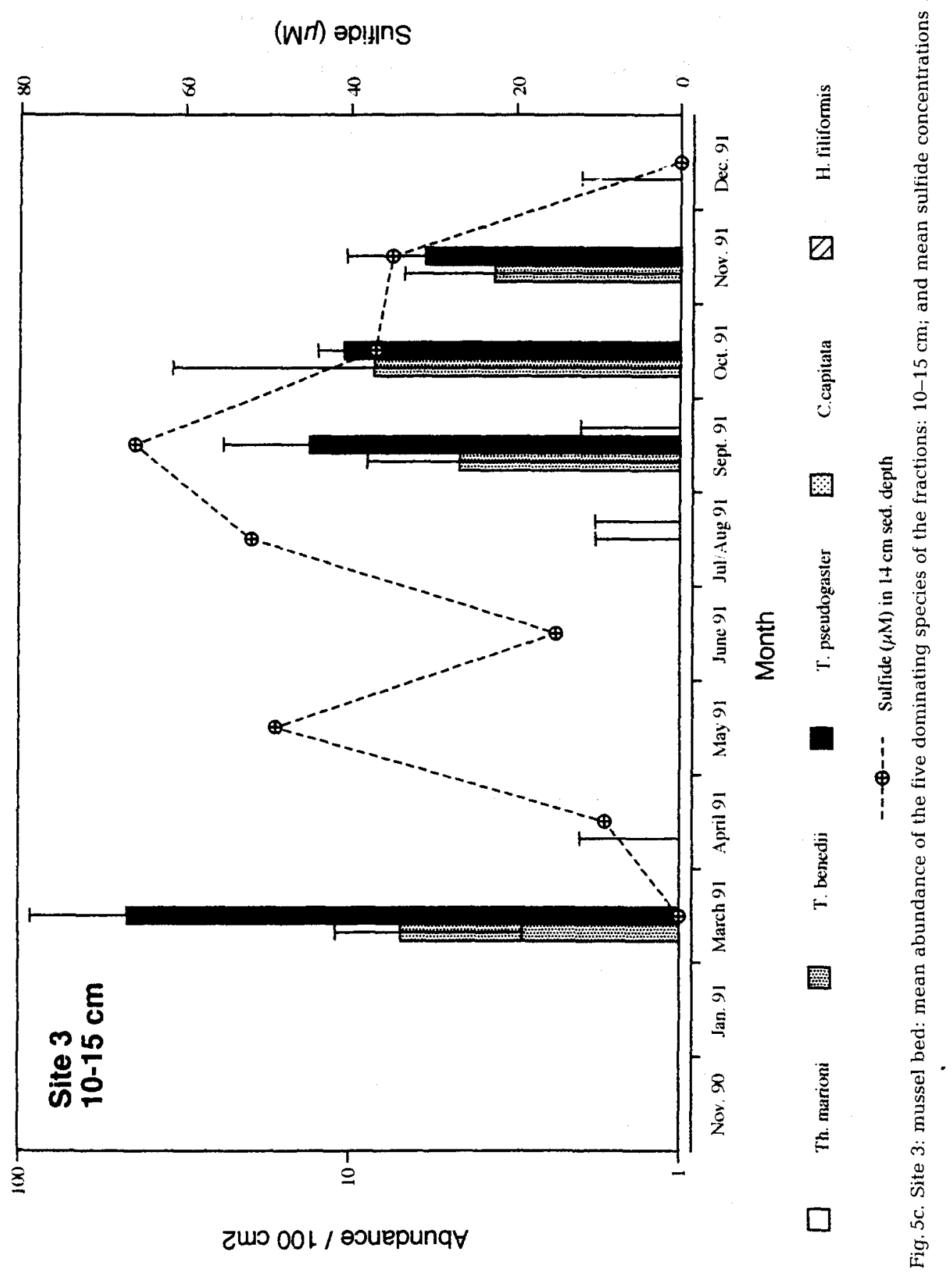


The summer situation was characterized by an increase in numbers of Hediste diversicolor. Capitella capitata attained the highest values in summer (maximum from 22 to 70 ind. $/ 100 \mathrm{~cm}^{2}$ in $0-5 \mathrm{~cm}$ depth, in July). In May, the population of Scoloplos armiger had a peak (61 ind. $/ 100 \mathrm{~cm}^{2}, 0-5 \mathrm{~cm}$ depth). Th. marioni was regularly found, but never attained a population density comparable to that at Sites 1 and 2.

\section{DISCUSSION}

The sulfide concentrations throughout the year showed high fluctuations; a clear pattern could not be discerned when the different sites were compared. Large oscillations were even observed in the replicates. The extremely patchy sulfide distribution observed in this study did not allow conclusions to be made on a more general seasonal and local pattern.

The comparison between sulfide concentrations and redox potential underlines the inadequacy of relating redox recordings to a pattern of oxygen and, indirectly, sulfide conditions. In many sediment layers where redox values often were clearly positive, sulfide and the concomitant anoxia could be recorded (see also Powell, 1989; Watling, 1991; Giere, 1992).

The twenty macrofauna species found in the area are common in the Wadden Sea tidal flats. But their occurrence is mostly restricted to the upper five centimetres of the sediment, their numbers decreasing considerably with depth. A good example of this prevailing pattern is the dominating species, Tharyx marioni, which was encountered abundantly only in the upper layers at low sulfide concentrations $(<50 \mu \mathrm{M})$. Only occasionally was this species found also at higher sulfide levels $(75-125 \mu \mathrm{M})$ at Site 1 (muddy) and Site 3 (mussel bed). But the population peaks of Th. marioni do not suggest a massively adverse relation to sulfidic conditions; this species is obviously able to tolerate a low amount of sulfide. A higher tolerance to sulfide is evident from the distribution pattern of the annelid species Tubificoides benedii, T. pseudogaster, Heteromastus filiformis, Capitella capitata and Hediste diversicolor. They were frequent also in the deeper layers of all three investigated sites where sulfide was present throughout the year in concentrations rising to $1 \mathrm{mM}$.

For most of these species, previous investigations have revealed specific adaptations to hypoxia and sulfide. The oligochaete Tubificoides benedii can maintain an aerobic metabolism in the presence of sulfide, when oxygen is available. Or the species can survive anoxia for a longer time, maintaining an anaerobic metabolism when oxygen is lacking (Dubilier, 1993; Dubilier et al., 1994). It seems that the sulfide penetrating into the worms can be detoxified by oxidation to thiosulfate. Metabolic pathways for sulfide detoxification were also found in Hediste diversicolor (Vismann, 1990). Heteromastus filiformis survived, in tolerance experiments, high sulfide concentrations (490-720 $\mu \mathrm{M})$ for more than $20 \mathrm{~h}$ (Niemeyer, 1989).

The situation in Capitella capitata is complicated by the presence of a species complex with a different physiological adjustment to hydrogen sulfide (Gamenick \& Giere, 1994). Within this complex, the larger sibling species, well adapted to hypoxia, seems to be restricted to the deeper, sulfide-rich sediment layers.

For Tubificoides pseudogaster, the physiological range of adaptation to hypoxic, sulfidic sediments has not been studied in detail. Pfannkuche (1980a) found the species in 
the brackish Schlei fjord under very low oxygen concentrations, as indicated by the redox potential recordings. Contrastingly, in the Limfjord, the species was recorded from sandy bottoms under "relatively good oxygen conditions" (Pfannkuche, 1980b). The distribution pattern in the present study suggests the inclusion of $T$. pseudogaster as a "sulfide species" with the possible existence of a metabolic pathway comparable to and as effective as those described above in the other species.

\section{CONCLUSIONS}

The macrofauna in the tidal flats of the Wadden Sea represents a predominantly oxiphilic benthos dominated by annelids. It is, however, temporarily exposed to sulfidic and hypoxic sediment conditions. The distribution pattern of the main species, discussed above, reflects a wide tolerance range for these ecological key factors in fine, sheltered sediments. But, as yet, data on the field situation and on the seasonal range of sulfide in the sediment are scarce. Sulfide formation is of high temporal and local variability, and annelid distribution is patchy and irregular. In combination with their fairly high tolerance to hydrogen sulfide, this may explain why general conclusions on a consistent pattern relating the occurrence of hydrogen sulfide to the distribution of these character species cannot, as yet, be drawn. Interaction with other factors, which cannot be excluded in field studies, will further blur the picture. Specifically for tubificids, grain size distribution seems of predominant importance (Giere \& Pfannkuche, 1982).

Nevertheless, the decisive role of hydrogen sulfide in the ecology of soft-bottom endobenthos in tidal flats, that emerges from experimental studies, requires further, longterm field studies on this abiotic key factor. Only then and in combination with experimental data backing can a better understanding of the field situation be achieved.

Acknowledgements. We are indebted to the Biologische Anstalt Helgoland, Wattenmeerstation List, for laboratory and boarding room, as well as for logistical support. This work was part of an interdisciplinary research project "Sulfide and Methane Based Ecosystems", funded by the EC (MAST 0044-C).

\section{LITERATURE CITED}

Buchanan, J. B., 1984. Sediment analyses. In: Methods for the studies of marine benthos. Ed. by N. A. Holmes \& A. D. McIntyre. Blackwell, Oxford, 41-65. (IBP Handbook. 16)

Dubilier, N., 1993. Ökophysiologische und morphologische Anpassungen des marinen Oligochaeten Tubificoides benedii (d'Udekem) an Sauerstoffmangel und Sulfid. Shaker, Aachen, $136 \mathrm{pp}$.

Dubilier, N., Giere, O. \& Grieshaber, M., 1994. Concomitant effects of sulfide and hypoxia on the aerobic metabolism of the marine oligochaete Tubificoides benedii. - J. exp. Zool. 269, 287-297.

Gamenick, I. \& Giere, O., 1994. Aspects of population dynamics and the ecophysiology of Capitella capitata from North Sea intertidal flats. Evidence for two sibling species. (Polychaete Colloquium Proceedings, Cardiff). - Polychaete Res. 16, 44-47.

Giere, O., 1992. Benthic life in sulfidic zones of the sea - ecological and structural adaptations to a toxic environment. - Verh. dt. zool. Ges. 85.2, 77-93.

Giere, O. \& Pfannkuche, O., 1982. Biology and ecology of marine Oligochaeta. A review. Oceanogr. mar. Biol. 20, 173-308.

Giere, O., Eleftheriou, A. \& Murison, D. J., 1988. Abiotic factors. In: Introduction to the study of meiofauna. Ed. by R. P. Higgins \& H. Thiel. Smithsonian Instn Press, Washington, 61-78.

Gilboa-Garber, N., 1971. Direct spectrophotometric determination of inorganic sulfide in biological materials and in other complex mixtures. - Analyt. Biochem. 42, 129-133. 
Grieshaber, M. K., Hardewig, I., Kreutzer, U. \& Pörtner, H.-O., 1994. Physiological and metabolic responses to hypoxia in invertebrates. - Rev. Physiol. Biochem. Pharmacol, 125, 43-147.

Howarth, R. W., Giblin, A., Gale, J., Peterson, B. J. \& Luther, G. W., 1983. Reduced sulfur compounds in the pore waters of a New England salt marsh. - Ecol. Bull., Stockh. 35, 135-152.

Howes, B. L., Dacey, J. W. \& Wakeham, S. G., 1985. Effects of sampling technique on measurements of porewater constituents in salt marsh sediments. - Limnol. Oceanogr. 30, 221-227.

Niemeyer, A. S., 1989. Zur Ultrastruktur von Heteromastus filiformis (Annelida; Polychaeta) und ihrer möglichen Beziehung zu dessen Vorkommen in der Sulfidzone des Wattes. Dipl.Arb., Univ. Hamburg, $74 \mathrm{pp}$.

Pfannkuche, O., 1980a. Distribution and abundance of Tubificidae and Naididae (Oligochaeta) in a brackish-water fjord, with special reference to the $\alpha$-mesohaline zone. - Neth. J. Sea Res. 14, 78-93.

Pfannkuche, O. 1980b. Aquatic Oligochaeta (Annelida) from the littoral zone of the Limfjord (Denmark). - Verh. naturwiss. Ver. Hamburg 23, 249-254.

Powell, E., 1989. Oxygen, sulfide and diffusion: Why thiobiotic meiofauna must be sulfide-insensitive first-order respirers. - J. mar. Res. 47, 887-983.

Reise, K., 1985. Tidal flat ecology. An experimental approach to species interactions. Springer, Berlin, $191 \mathrm{pp}$.

Vismann, B., 1990. Sulfide detoxification and tolerance in Nereis (Hediste) diversicolor and Nereis (Neanthes) virens (Annelida: Polychaeta). - Mar. Ecol. Prog. Ser. 59, 229-238.

Vismann, B., 1991. Sulfide tolerance: Physiological miechanisms and ecological implications. Ophelia 34, 1-27.

Watling, L., 1991. The sedimentary milieu and its consequences for resident organisms. - Am. Zool. $31,789-796$.

Wohlenberg, E., 1937. Die Wattenmeer-Lebensgemeinschaften im Königshafen von Sylt. - Helgoländer wiss. Meeresunters. 1, 1-92. 